\title{
Kajian Karakteristik Fisikokimia Tepung Belimbing Manis dengan Perbedaan Metode dan Suhu Pengeringan
}

\author{
Riska Yulis Hidayana*1, Sukardi ${ }^{1}$, Desiana Nuriza Putri ${ }^{1}$ \\ Program Studi Teknologi Pangan, Fakultas Pertanian-Peternakan, Universitas Muhammadiyah \\ Malang, Malang, Indonesia \\ *Corresponding author email: riskayulishidayana@gmail.com
}

\begin{abstract}
Sweet star fruit (Averhoa Carambola L.) is an abundant commodity which has a short shelf life and easy to be damaged. The decrease in the quality of sweet star fruit is not only caused by chemical components but also physical properties. However, to be able to improve the quality of $s$ weet star fruit, it can be processed into semi-finished product such as flour. This research aimed to analyze the interaction between drying method and drying temperature at sweet star fruit flour to the physicochemical characteristics. The experimental design used was a Randomized Block Design (RBD), namely differences in drying methods and drying temperatures, A1S1 (freezing+cabinet dryer $55^{\circ} \mathrm{C}$ ), A2S1 (freezing+oven $55^{\circ} \mathrm{C}$ ), $A 3 S 1$ (cabinet dryer $55^{\circ} \mathrm{C}$ ), A4S1 (oven $55^{\circ} \mathrm{C}$ ), A1S2 (freezing+cabinet dryer $60^{\circ} \mathrm{C}$ ), A2S2 (freezingtoven $60^{\circ} \mathrm{C}$ ), A3S2 (cabinet dryer $60^{\circ} \mathrm{C}$ ), A4S2 (oven $60^{\circ} \mathrm{C}$ ). The observation parameters include moisture content, vitamin $C$, crude fiber content, antioxidants activity, total sugar, yield, and color intensity. The data is obtained followed by DMRT (Duncan's Multiple Range Test). The results of this research show that the A2S1 treatment using the oven drying method with a temperature of $55^{\circ} \mathrm{C}$ and the preliminary process in the form of microwave was the best treatment based on the results of physicochemical analysis with a moisture content of 17,64\%, Vitamin C 41,00mg/100g, crude fiber content 16,24\%, 19,25\% total sugar, $12.45 \%$ yield, 17,28\% antioxidant activity, brightness $(+) 63.56$, redness $(+) 8,70$, yellowness $(+) 12.36$.
\end{abstract}

Keywords: Drying methods, Drying temperature, $S$ weet star fruit, $S$ weet starfruit flour

\begin{abstract}
Abstrak. Belimbing manis merupakan komoditas cukup melimpah yang memiliki masa simpan pendek dan mudah rusak. Penurunan kualitas belimbing manis tidak hanya disebabkan oleh komponen kimia tetapi juga sifat fisik. Namun untuk dapat meningkatkan kualitas belimbing manis dapat diolah menjadi produk setengah jadi yaitu tepung. Penelitian ini bertujuan untuk menganalisis interaksi antara metode pengeringan dan suhu pengeringan pada tepung belimbing manis terhadap karakteristik. Rancangan percobaan yang digunakan adalah Rancangan Acak Kelompok (RAK), yakni perbedaan metode pengeringan dan perbedaan suhu pengeringan, yaitu A1S1 (freezing+cabinet dryer $55^{\circ} \mathrm{C}$ ), $\mathrm{A} 2 \mathrm{~S} 1$ (freezing+oven $55^{\circ} \mathrm{C}$ ), A3S1 (cabinet dryer $55^{\circ} \mathrm{C}$ ), A4S1 (oven $55^{\circ} \mathrm{C}$ ), $\mathrm{A} 1 \mathrm{~S} 2$ (freezing+cabinet dryer $60^{\circ} \mathrm{C}$ ), A2S2 (freezing+oven $60^{\circ} \mathrm{C}$ ), A3S2 (cabinet dryer $60^{\circ} \mathrm{C}$ ), A4S2 (oven $60^{\circ} \mathrm{C}$ ). Parameter pengamatan meliputi kadar air, vitamin $\mathrm{C}$, kadar serat kasar, aktivitas antioksidan, gula total, rendemen, dan intensitas warna. Hasil analisa kemudian diolah menggunakan analisis ragam (ANOVA) pada $\alpha=5 \%$, apabila berpengaruh nyata
\end{abstract}


maka data yang diperoleh dilanjutkan dengan uji pembeda menggunakan uji. .Hasil dari penelitian ini menunjukkan bahwa perlakuan A2S1 dengan menggunakan metode pengeringan oven dengan suhu $55^{\circ} \mathrm{C}$ serta proses pendahuluan berupa microwave dan freezing menjadi perlakuan terbaik berdasarkan hasil analisa fisikokimia dengan kadar air 17,64\%, Vitamin C 41,00mg/100g, kadar serat kasar 16,24\%, gula total 19,25\%, rendemen $12,45 \%$, aktivitas antioksidan 17,28\%, tingkat kecerahan $(+) 63,56$, tingkat kemerahan (+)8,70, tingkat kekuningan (+)12,36.

Kata kunci: Belimbing Manis, Metode pengeringan, Suhu pengeringan, Tepung belimbing manis

\section{PENDAHULUAN}

Belimbing manis termasuk dalam salah satu hasil perkebunan indonesia yang memiliki rasa manis serta menyegarkan. Buah belimbing manis memiliki kelebihan dari segi kandungan gizinya yaitu kandungan vitamin $\mathrm{C}$ yang cukup tinggi sebesar $35 \mathrm{mg}$. Selain itu juga memiliki kandungan kimia seperti saponin, flavonoid, steroid, glikosida, protein, lemak, kalsium, fosfor, besi dan vitamin B (Departemen Gizi Kesehatan RI, 2004). Ketertarikan terhadap rasa serta manfaat pada buah belimbing manis telah meningkatkan permintaan belimbing manis dari tahun ke tahun yang meningkat sebesar 8,9\% (19.900 ton) pada tahun 20092015 (Deptan,2009). Produksi belimbing manis yang semakin naik menyebabkan bahan baku belimbing manis melimpah serta mempunyai kadar air yang tinggi yaitu berkisar $90 \%$ sehingga dapat menyebabkan buah belimbing manis mudah cepat rusak dan juga mempunyai umur simpan yang cukup singkat yaitu sekitar 3-4 hari pada suhu ruang. Oleh karena itu perlu dilakukan proses pengolahan untuk memperpanjang daya simpan belimbing manis, yaitu berupa tepung. Tepung merupakan salah satu bahan pangan yang memiliki kenampakan bubuk atau serbuk serta merupakan hasil dari proses penggilingan yang kemudian dilakukan proses penganyakan sehingga menghasilkan ukuran produk yang seragam (Ditjen PPHP, 2012).

Keuntungan mengolah bahan baku pangan menjadi bentuk tepung, yaitu daya simpan lebih lama, menghemat ruang simpan dan mempermudah transportasi meningkatkan nilai guna karena bentuk tepung mudah diolah menjadi berbagai jenis produk makanan dan dapat diformulasi menjadi tepung komposit, dalam upaya untuk meningkatkan nilai gizi produk olahan (Suhardi, 2006). Secara garis besar proses penepungan diawali dengan pencucian, pengecilan ukuran, pengeringan, penghalusan dan pengayakan. Pengeringan dapat dilakukan dengan berbagai macam atau cara yaitu pengeringan matahari dan pengeringan buatan (alat), alat yang biasa digunakan adalah oven dan cabinet dryer. Adapun faktor yang dapat mempengaruhi pengeringan yaitu faktor yang berhubungan dengan udara pengering dan faktor yang berhubungan dengan sifat bahan yang dikeringkan. Faktor-faktor pertama adalah suhu, kecepatan 
volumetric, aliran udara pengering dan kelembaban udara. Faktor-faktor yang kedua adalah ukuran bahan, kadar air awal dan tekanan parsial di dalam bahan (Ratnasari, 2014).

Pengembangan tepung berbasis buah segar telah cukup banyak ditemukan baik pada level nasional maupun internasional, namun untuk buah belimbing manis masih sangat jarang ditemukan dalam lingkungan masyarakat baik nasional maupun internasional. Umumnya hanya diolah menjadi produk bahan cair saja seperti sirup, sari buah, dll. Oleh karena itu perlu dilakukan penelitian tentang pembuatan tepung belimbing manis dengan perbedaan metode dan suhu pengeringan untuk mengetahui pengaruh karakteristik fisikokimia tepung belimbing manis serta agar dapat dijadikan sebagai salah satu diversifikasi bahan pangan. Pada penelitian ini menggunakan metode buatan dengan alat pengering cabinet dryer dan oven dengan perbedaan suhu yaitu $55^{\circ} \mathrm{C}$ dan $60^{\circ} \mathrm{C}$, serta menggunakan perlakuan pendahuluan dengan blanching (microwave) dan pembekuan/Freezing pada belimbing manis, dikarenakan belimbing manis dapat mengalami browning setelah di iris.

\section{METODE PENELITIAN}

Alat

Alat yang digunakan dalam penelitian ini terdiri dari alat pembuatan tepung dan alat untuk analisis. Adapun alat untuk pembuatan tepung yaitu pisau, talenan, baskom, timbangan digital Merk Nankai 10kg dan Merk Nankai 300kg, oven rak susun 8, cabinet dryer, blender miyako, dan ayakan. Peralatan yang digunakan untuk analisis terdiri dari timbangan analitik, oven, desikator, kurs porselen, tanur, kertas saring, labu ukur, lemari asam, pompa vakum, erlenmeyer, pipet tetes, gelas ukur, hotplate, gelas beaker, colour reader CR-10 merk Konica Minolta, aluminium foil.

\section{Bahan}

Bahan utama yang digunakan dalam penelitian ini yaitu belimbing manis dengan indeks kematangan 3-4 buah berwarna hijau-kuning yang diperoleh dari toko buah tlogomas malang. Bahan-bahan yang digunakan untuk analisa diperoleh dari Laboratorium Teknologi Pangan Universitas Muhammadiyah Malang yaitu iodin, indikator PP, larutan $\mathrm{NaOH} 3,25 \%$, indikator amilum, $\mathrm{H}_{2} \mathrm{SO}_{4}$ 96\%, Anthrone, DPPH, aquades dan bahan pendukung lainnya s eperti antibuih(kalsium alginat), ethanol 96\%, glukosa didapat dari luar labororatorium Teknologi Pangan Universitas Muhammadiyah Malang.

\section{Desain Penelitian}

Penelitian ini menggunakan Rancangan Acak Kelompok (RAK) dengan perlakuan faktorial. Faktor pertama adalah perbedaan metode pengeringan yang terdiri dari 4 level yaitu freezer + cabinet dryer, freezer+oven, cabinet dryer dan 
oven. Sementara faktor kedua yaitu suhu pengeringan yang terdiri dari 2 level yaitu $55^{\circ} \mathrm{C}$ dan $60^{\circ} \mathrm{C}$.

\section{Pembuatan Tepung Belimbing Manis dengan Cabinet Dryer dan Oven dengan Perlakuan Freezing}

Pembuatan tepung belimbing manis diawali dengan pencucian hingga bersih, pengirisan dengan ketebalan $\pm 0,5 \mathrm{~cm}$, kemudian dilakukan blanching dengan microwave selama 5-10 detik. Setelah itu dilakukan pembekuan atau freezing dalam freezer selama 24 jam, kemudian dilakukan pengeringan pada suhu $55^{\circ} \mathrm{C}$ dan $60^{\circ} \mathrm{C}$ selama 24 jam. Selanjutnya dilakukan penggilingan dengan blender dan pengayakan dengan ayakan 80 mesh hingga diperoleh hasil akhir tepung belimbing manis yang mengacu pada Brantas (2017).

\section{Pembuatan Tepung Belimbing Manis dengan Cabinet Dryer dan Oven dengan Perlakuan Tanpa Freezing}

Pembuatan tepung belimbing manis diawali dengan pencucian hingga bersih, pengirisan dengan ketebalan $\pm 0,5 \mathrm{~cm}$, kemudian dilakukan blanching dengan microwave selama 5-10 detik. Setelah itu dilakukan proses pengeringan pada suhu $55^{\circ} \mathrm{C}$ dan $60^{\circ} \mathrm{C}$ selama 24 jam. Selanjutnya dilakukan penggilingan dengan blender dan penganyakan dengan ayakan 80 mesh hingga diperoleh hasil akhir tepung belimbing manis yang mengacu pada Brantas (2017).

\section{Parameter Penelitian}

Parameter penelitian yang digunakan antara lain uji kimia, dan fisik. Pengujian sifat kimia berupa kadar air metode oven (AOAC,2005), kadar vitamin $\mathrm{C}$ metode iodimetri (AOAC,2002), rendemen (AOAC,2005), kadar serat kasar (Sudarmadji, 2003), aktivitas antioksidan (Yue dan Xu, 2008), dan kadar gula total (Sudarmadji, 1997). Pengujian fisik berupa intensitas warna dengan colour reader (Yuwono dan Susanto, 2001).

\section{Analisa Data}

Pengolahan data dilakukan dengan menggunakan analisis ragam (ANOVA) pada $\alpha=5 \%$ untuk mengetahui apakah perlakuan memberikan pengaruh nyata atau tidak terhadap karakteristik fisikokimia tepung belimbing manis. Apabila terjadi pengaruh nyata maka data yang diperoleh akan dilanjutkan dengan uji pembeda menggunakan uji DMRT (Duncan's Multiple Range Test).

\section{HASIL DAN PEMBAHASAN Analisis Bahan Baku}

Analisa bahan baku penelitian ini dilakukan pada buah segar belimbing manis. Analisa ini dilakukan untuk mengetahui kandungan kimia yang terdapat dalam bahan baku sehingga nantinya dapat menghasilkan produk kualitas terbaik. 
Tabel 1. Analisa Bahan Baku Belimbing Manis

\begin{tabular}{cc}
\hline Parameter & Jumlah \\
\hline Kadar Air (\%) & 90,38 \\
Vitamin C (mg/100g) & 52,81 \\
Aktivitas Antioksidan (\%) & 80,22 \\
Kadar Serat (\%) & 8,50 \\
Gula Total (\%) & 3,16 \\
\hline
\end{tabular}

Data yang diperoleh bahwa kandungan air belimbing manis sebesar 90,82\% sedangkan menurut Departemen Kesehatan RI (2004) kadar air belimbing manis sebesar 90\%. Adanya perbedaan kandungan kimia dapat disebabkan karena penggunaan varietas dan tingkat kematangan belimbing manis yang berbeda. Analisa vitamin C belimbing manis menunjukkan hasil sebesar 52,81mg/100g sedangkan menurut beberapa penelitian menyatakan bahwa vitamin $\mathrm{C}$ yang terdapat didalam buah belimbing manis lebih rendah yaitu sebesar 35mg Departemen Kesehatan RI (2004) dan 22,3 mg Silva dkk (2016). Hal ini dapat terjadi diduga karena perbedaan buah belimbing manis yang digunakan serta tingkat kematangan buah yang berbeda. Menurut Fama (2005) semakin matang buah ditandai dengan warna buah kekuningan memiliki rasa manis yang tinggi sedangkan buah yang ditandai dengan warna buah hijau kekuningan memiliki rasa asam yang dominan.

Kandungan serat buah belimbing manis yang terdapat pada tabel 1 sebesar 8,50 \% sementara menurut Kartikasari (2012) kandungan serat buah belimbing manis sebesar 0,90\%. Hal ini dapat terjadi diduga karena perbedaan varietas belimbing manis yang digunakan. Menurut Fama (2005) menyatakan bahwa belimbing wulan tidak memiliki kandungan serat pada buahnya sedangkan buah belimbing manis dewi memiliki cukup kandungan serat. Hasil analisa aktivitas antioksidan buah belimbing manis sebesar 80,22\% namun menurut beberapa penelitian yakni Silva \& Sirasa (2018) dan (Lim dkk., 2007) secara berturut-turut menyatakan bahwa aktivitas antioksidan sebesar 18,52\% dan 3,8\%. Adanya perbedaan dalam penelitian ini diduga kerena perbedaan jenis varietas yang digunakan serta tingkat kematangan buah sehingga dapat terjadi perbedaan nilai kandungan antioksidan yang dihasilkan.

Analisa gula total menunjukkan hasil sebesar 3,16\% sementara menurut beberapa penelitian menyatakan bahwa gula total yang terdapat dalam buah belimbing manis sebesar 5,69\% Rachmayati dkk (2017) dan 2,94\% Mawarni dkk (2018). Hal ini dapat terjadi diduga karena perbedaan varietas belimbing manis yang digunakan. Menurut Baswarsiati (2017) belimbing tasik madu memiliki rasa 
yang manis yaitu $11-12 \%$, selain itu juga apabila semakin matang buah maka rasa manis yang terdapat dalam buah akan meningkat.

\section{Kadar Air}

Berdasarkan hasil analisa ragam menunjukkan bahwa adanya pengaruh sangat nyata pada perlakuan perbedaan suhu tepung belimbing manis, sedangkan pada perbedaan metode menunjukkan hasil bahwa tidak berpengaruh nyata terhadap kandungan kadar air tepung belimbing manis. Hasil kadar air tepung belimbing manis ditampilkan pada Gambar 1.

\begin{tabular}{|c|c|c|c|c|c|c|}
\hline \multirow{6}{*}{ 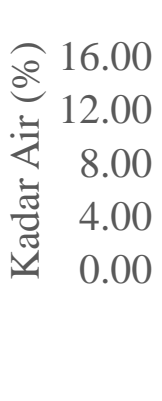 } & 15,82 & 15,43 & 17,21 & 16,41 & & \\
\hline & & & & & \multicolumn{2}{|c|}{ Keterangan : } \\
\hline & & & & & & : Freezing+cabinet dryer \\
\hline & & & & & & :Freezingtoven \\
\hline & A1 & $\mathrm{A} 2$ & A3 & A4 & A3 & : Cabinet dryer \\
\hline & \multicolumn{4}{|c|}{ Metode Pengeringan } & A4 & : Oven \\
\hline
\end{tabular}

Gambar 1. Histogram Kadar Air Tepung Belimbing Manis Perlakuan Metode

Berdasarkan data statistik pada Gambar 1 menunjukkan bahwa tidak berpengaruh nyata terhadap kandungan kadar air tepung belimbing manis. Adapun hasil analisa kadar air pada perlakuan perbedaan metode berkisar antara 15,3\% hingga 17,21\%. Hal ini terjadi dapat disebabkan beberapa faktor yaitu aliran udara, kelembaban udara, laju pengeringan, suhu pengeringan, dan tekanan uap air di udara. Peranan udara dalam pengeringan yakni sebagai penghantar panas ke bahan yang dikeringkan (Subandi dkk., 2015). Menurut (Taufiq, 2004) mengemukakan bahwa apabila laju pengeringan atau laju penguapan air bahan melambat maka kelembaban udara menjadi tinggi begitu juga sebaliknya, yang mana hal tersebut dapat mempengaruhi hantaran panas pada bahan yang akan dikeringkan.

Selain itu dengan adanya perbedaan alat pengeringan diduga dapat menyebabkan kadar air pada bahan menurun atupun masih tinggi. Hal ini di dukung oleh penelitian (Rif'an et al., 2017) yang menyatakan bahwa kadar air terendah sup labu kuning instan dengan menggunakan oven dryer sebesar 10,70\% dibandingkan dengan menggunakan cabinet dryer yaitu sebesar 19,89\%. Hal ini disebabkan karena kecepatan aliran udara serta suhu yang tinggi dalam ruang oven dryer dapat menyebabkan air menguap lebih cepat sehingga terjadi perpindahan panas secara konveksi dan radiasi yang dapat menimbulkan air menguap lebih cepat, sedangkan pada pengering cabinet dryer hanya 
menggunakan satu pemanas yang mana hal tersebut dapat mengakibatkan proses penguapan kurang optimal.

Tabel 2. Rerata Nilai Kadar Air Tepung Belimbing Manis Perlakuan Suhu

\begin{tabular}{llc} 
& Perlakuan & Kadar Air (\%) \\
\hline $\mathrm{S} 1$ & $\left(\right.$ Suhu $\left.55^{\circ} \mathrm{C}\right)$ & $17,92 \mathrm{a}$ \\
$\mathrm{S} 2$ & $\left(\right.$ Suhu $\left.60^{\circ} \mathrm{C}\right)$ & $14,51 \mathrm{~b}$ \\
\hline
\end{tabular}

Keterangan : Angka yang diikuti huruf yang sama meunjukkan tidak berbeda nyata berdasarkan uji DMRT ( $a=5 \%)$

Berdasarkan Tabel 2 menunjukkan hasil kadar air tertinggi pada perlakuan S1 sebesar 17,92\%, sedangkan terendah pada perlakuan S2 sebesar 14,51\%. Rendahnya kadar air dipengaruhi oleh suhu panas yang digunakan, semakin tinggi suhu yang digunakan maka akan semakin rendah juga hasil kadar air yang diperoleh. Hal ini sesuai dengan pernyataan Kuliahsari dkk. (2018) yang menyatakan bahwa dengan menggunakan suhu pengeringan yang tinggi dapat menyebabkan kadar air pada produk pangan akan semakin rendah dan juga semakin tinggu suhu yang digunakan akan menguapkan air pada bahan semakin banyak. Hal ini sejalan dengan penelitian Murti (2017) bahwa turunnya kadar air pada bahan disebabkan karena suhu, kelembapan dan kecepatan serta jenis bahan yang dikeringkan. Selain itu juga terdapat faktor lain yang dapat mempengaruhi nilai kadar air bahan yaitu perbedaan bahan yang digunakan, kematangan dari bahan yang digunakan.

\section{Vitamin C}

Berdasarkan hasil analisa ragam menunjukkan bahwa tidak terdapat interaksi antara perlakuan perbedaan metode dan perbedaan suhu terhadap kandungan vitamin C tepung belimbing manis. Secara terpisah perlakuan perbedaan metode dan suhu pengeringan memberikan hasil tidak berpengaruh nyata terhadap kandungan vitamin $\mathrm{C}$ tepung belimbing manis. Hasil kandungan vitamin $\mathrm{C}$ perbedaan metode pengeringan dapat dilihat pada Gambar 2.
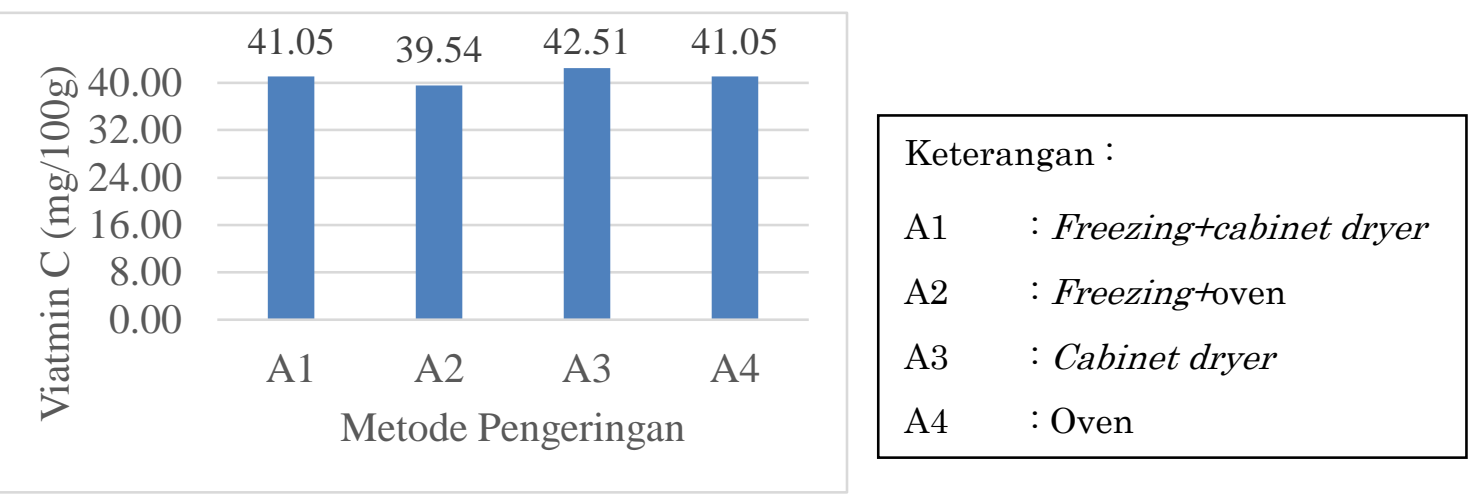

Gambar 2. Histogram Vitamin C Tepung Belimbing Manis Perlakuan Metode 
Berdasarkan Gambar 2 hasil analisa kandungan vitamin $\mathrm{C}$ pada perlakuan perbedaan metode berkisar antara $39,54 \mathrm{mg} / 100 \mathrm{~g}$ hingga $42,50 \mathrm{mg} / 100 \mathrm{~g}$. Adanya proses freezing menurut khadatkar dkk (2004) dapat menurunkan kandungan vitamin $\mathrm{C}$ pada bahan makanan. Hal itu terjadi saat proses thawing pada suatu bahan makanan berlangsung, karena vitamin $\mathrm{C}$ merupakan vitamin yang larut dalam air. Menurut Brantas (2017) menyatakan bahwa kandungan vitamin C pada tepung apel dengan adanya perlakuan pendinginan atau tanpa pendinginan memiliki hasil yang tidak berpengaruh nyata yaitu berkisar antara $5,39 \mathrm{mg} / 100 \mathrm{~g}$ hinggan 5,84mg/100g. Selain itu ada beberapa faktor yang dapat mempengaruhi prosess pengeringan yaitu salah satunya kelembaban udara, dimana kelembaban udara dapat berpengaruh atau menghambat dalam proses pemindahan uap air dari dalam bahan. Hal ini sejalan dengan Widyotomo dan Mulato (2005) dalam Rahayuningtyas \& Kuala (2016) menyatakan bahwa apabila semakin rendah kelembapan udara pengeringan maka kemampuan dalam menyerap uap air akan semakin besar. Begitu juga sebaliknya, apabila kelembapan udara pengeringan semakin besar maka kemampuan dalam menyerap air akan semakin kecil.

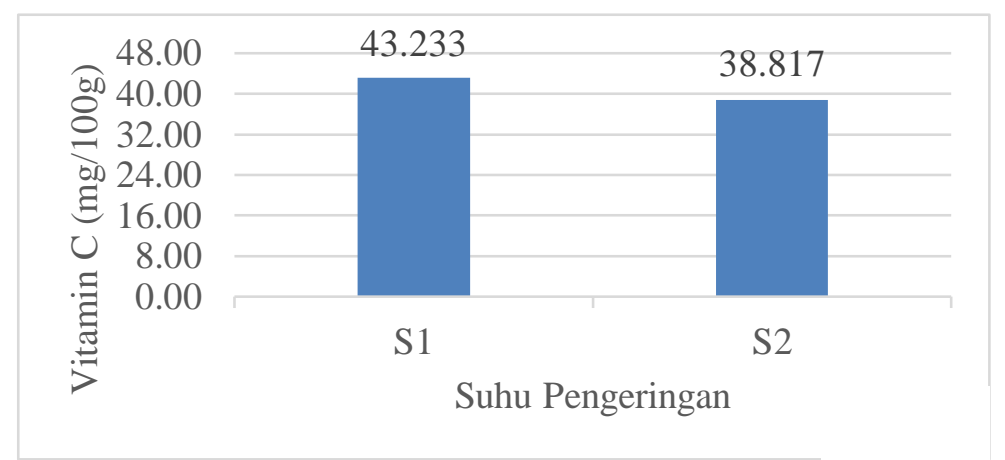 Keterangan :
A1 : Freezing+cabinet dryer
A2 : Freezingtoven
A3 : Cabinet dryer
A4 : Oven

Gambar 3. Histogram Vitamin C Tepung Belimbing Manis Perlakuan Suhu

Berdasarkan Gambar 3 kandungan vitamin C menunjukkan bahwa perbedaan suhu pengeringan memiliki nilai rerata $\mathrm{S} 1\left(55^{\circ} \mathrm{C}\right)$ dan $\mathrm{S} 2\left(60^{\circ} \mathrm{C}\right)$ yaitu berkisar 38,81mg/100g dan 43,23mg/100g. Perbedaan suhu pengeringan memberikan hasil yang tidak berpengaruh nyata terhadap kandungan vitamin $\mathrm{C}$ pada tepung belimbing manis. Hal ini dapat terjadi diduga karena adanya perbedaan luas permukaan bahan yang digunakan, dimana dapat menyebabkan penyerapan panas pada bahan tidak merata sehingga kandungan vitamin $\mathrm{C}$ di dalam bahan tidak terjadi kerusakan, dan penggunaan suhu yang kurang optimal dikarenakan suhu yang digunakan pada alat pengering kurang stabil sehingga pemberian panas pada bahan kurang sempurna. 


\section{Hasil Analisis Rendemen, Aktivitas Antioksidan, Serat Kasar dan Gula Total Rendemen}

Berdasarkan Tabel 4. hasil rendemen tertinggi pada perlakuan A2 sebesar 12,33\%, sedangkan rendemen terendah pada perlakuan A3 sebesar 11,50\%. Hal ini terjadi karena adanya perlakuan freezing, hal ini sejalan dengan Asgar (2017) menyatakan bahwa kadar air bahan yang disimpan dalam freezer akan menyebabkan penurunan suhu sehingga dapat mengakibatkan adanya peningkatan pada selisih energi $\mathrm{H}_{2} \mathrm{O}$ di antara bahan dan udara. Adanya peningkatan selisih ini dapat menyebabkan adanya peningkatan air yang hilang dari bahan. Oleh karena itu kadar air yang hilang semakin banyak dengan seiring penurunan suhu penyimpanan. Selain itu juga dapat dipengaruhi pada saat proses pengayakan dan perbedaan alat pengeringan, menurut Rif'an dkk, (2017) bahwa tepung jagung yang disaring menggunakan saringan dengan lubang kecil menghasilkan rendemen yang tinggi daripada yang disaring dengan menggunakan saringan lubang besar, karena pada saat pengayakan banyak tepung yang lengket di saringan sehingga menyebabkan lubang saringan menjadi mengecil dan menghambat tepung melewati saringan. Selain itu juga dapat disebabkan karena kecepatan aliran udara serta suhu yang tinggi dalam ruang oven dryer dapat menyebabkan air menguap lebih cepat sehingga terjadi perpindahan panas secara konveksi dan radiasi yang dapat menimbulkan air menguap lebih cepat dan elemen panas yang berdekatan dengan bahan dan yang terdapat pada dinding oven dapat membantu mentransfer energi lebih merata dengan dibantu oleh kipas oven untuk sirkulasi udara. Sedangkan pada pengering cabinet dryer hanya menggunakan satu pemanas yang mana hal tersebut dapat mengakibatkan proses penguapan kurang optimal.

Berdasarkan Tabel 4, perlakuan perbedaan suhu pengeringan terhadap rendemen tepung belimbing didapatkan hasil rendemen tertinggi pada perlakuan S1 sebesar 12,02\% dan terendah pada perlakuan S2 sebesar 11,66\%. Hal tersebut terjadi karena perbedaan suhu yang digunakan, apabila semakin meningkat suhu pengeringan yang digunakan maka menurun hasil rendemennya begitu juga sebaliknya. Hal ini sesuai dengan Kuliahsari dkk. (2018) bahwa dengan seiring meningkatnya suhu pengeringan yang digunakan dapat mengakibatkan perbedaan suhu antara medium pemanas dan bahan pangan menjadi semakin besar, hal tersebut mengakibatkan air yang terkandung pada bahan akan semakin banyak yang menguap. Oleh sebab itu, massa bahan menjadi berkurang dan rendemen yang dihasilkan semakin rendah. 
Tabel 4. Hasil Analisis Rendemen, Aktivitas Antioksidan, Serat Kasar dan Gula Total Tepung Belimbing Manis

\begin{tabular}{lcccc}
\hline \multicolumn{1}{c}{ Perlakuan } & $\begin{array}{c}\text { Rendemen } \\
(\%)\end{array}$ & $\begin{array}{c}\text { Aktivitas } \\
\text { Antioksidan }(\%)\end{array}$ & $\begin{array}{c}\text { Kadar Serat } \\
\text { Kasar (\%) }\end{array}$ & $\begin{array}{c}\text { Gula Total } \\
(\%)\end{array}$ \\
\hline A1 (Freezing+cabinet dryer) & $11,77 \mathrm{~b}$ & $25,32 \mathrm{a}$ & $16,05 \mathrm{~b}$ & $23,50 \mathrm{~b}$ \\
A2 (Freezing+oven) & $12,33 \mathrm{a}$ & $13,76 \mathrm{~b}$ & $18,11 \mathrm{a}$ & $31,37 \mathrm{a}$ \\
A3 (Cabinet dryer) & $11,50 \mathrm{~b}$ & $30,06 \mathrm{a}$ & $12,40 \mathrm{c}$ & $12.87 \mathrm{c}$ \\
A4 (oven) & $11,75 \mathrm{~b}$ & $25,88 \mathrm{a}$ & $12,92 \mathrm{c}$ & $14,66 \mathrm{c}$ \\
\hline S1 (Suhu $\left.55^{\circ} \mathrm{C}\right)$ & $17,92 \mathrm{a}$ & $28,32 \mathrm{a}$ & $13,36 \mathrm{~b}$ & $12,07 \mathrm{~b}$ \\
S2 (Suhu $\left.60^{\circ} \mathrm{C}\right)$ & $14,51 \mathrm{~b}$ & $19,19 \mathrm{~b}$ & $16,38 \mathrm{a}$ & $29,12 \mathrm{a}$ \\
\hline
\end{tabular}

Keterangan : Angka yang diikuti huruf yang sama meunjukkan tidak berbeda nyata berdasarkan uji DMRT $(\alpha=5 \%)$

\section{Aktivitas Antioksidan}

Berdasarkan Tabel 4. hasil aktivitas antioksidan tertinggi pada perlakuan A3 sebesar 30,06\% dan terendah pada perlakuan A2 sebesar 13,76\%. Penurunan aktivitas antioksidan didalam tepung belimbing manis juga dapat disebabkan oleh beberapa senyawa yang tidak tahan terhadap panas yaitu flavonoid, saponin, vitamin A, dll yang tidak tahan atau sangat rentan terhadap panas. Adanya proses pendinginan dapat menyebabkan aktivitas antioksidan turun, hal ini sesuai dengan pernyataan Wulansari dkk. (2020) yang menyatakan bahwa laju kerusakan dapat menurunkan kapasitas antioksidan, yang mana laju kerusakan terbesar pada penyimpanan beku $(-10 \pm 2)^{\circ} \mathrm{C}$, dan juga adanya laju kerusakan total fenol dan kadar vitamin $\mathrm{C}$ pada penyimpanan suhu dingin $(5 \pm 2)^{\circ} \mathrm{C}$. Selain itu dengan adanya udara panas kecepatan tinggi pada alat pengering oven dan perlakuan blanching dengan menggunakan microwave dapat menyebakan menyebabkan penurunan aktivitas antioksidan dikarenakan antioksidan sangat rentan terhadap panas. Hal ini sejalan dengan (Subandi dkk., 2015) menyatakan bahwa oven menggunakan system aliran udara bebas yang berkecepatan tinggi serta dengan dibantu adanya exhaust blower yang dapat mempercepat udara pengeringan yang mana dapat menyebabkan pengeringan semakin cepat.

Berdasarkan Tabel 4. Perlakuan perbedaan suhu pengeringan terhadap aktivitas antioksidan tepung belimbing manis didapatkan hasil tertinggi pada perlakuan S1 sebesar 28,32\% dan terendah pada perlakuan S2 19,19\%. Hal ini dapat terjadi karena perbedaan suhu yang digunakan, apabila semakin tinggi suhu yang digunakan maka akan semakin rendah pula antioksidan yang dihasilkan, karena antioksidan merupakan senyawa yang sangat sensitif terhadap panas. Hal ini sesuai Kusuma dkk (2019) yang menyatakan bahwa apabila suhu pemanasan semakin tinggi dapat menyebabkan senyawa metabolit sekunder yang berperan sebagai antioksidan (senyawa flavonoid) menjadi rusak. 


\section{Kadar Serat Kasar}

Berdasarkan Tabel 4. hasil kadar serat kasar tertinggi pada perlakuan A2 sebesar 18,11\%, dan serat terendah pada perlakuan A3 sebesar 12,40\%. Hal ini dapat terjadi karena adanya freezing, yang dapat menghambat pertumbuhan mikroba atau enzim tertentu yang mana nantinya dapat memecah selulosa dan hemiselulosa pada suatu bahan pangan sehingga menghasilkan nilai kadar serat yang rendah, serta serat yang terkandung dalam buah belimbing manis yaitu selulosa dan hemiselulosa. Jenis serat selulosa dan hemiselulosa termasuk ke dalam serat tak larut air dan juga lebih sukar untuk diuraikan (Nilasari dkk, 2017). Hal ini sejalan dengan Paramita (2013) bahwa pada pembuatan tepung mangga dengan adanya perendaman pada air dingin memiliki kadar serat kasar tertinggi sebesar 3,7370\% dibandingkan dengan air biasa 3,4508\%. Selain itu juga, menurut Rifan dkk. (2017) bahwa kecepatan aliran udara serta suhu yang tinggi dalam ruang oven dryer dapat menyebabkan air menguap lebih cepat sehingga terjadi perpindahan panas secara konveksi dan radiasi yang dapat menimbulkan air menguap lebih cepat, selain itu elemen panas yang berdekatan dengan bahan dan yang terdapat pada dinding oven dapat membantu mentransfer energi lebih merata dengan dibantu oleh kipas oven untuk sirkulasi udara. Sedangkan pada pengering cabinet dryer hanya menggunakan satu pemanas yang mana hal tersebut dapat mengakibatkan proses penguapan panas kurang optimal.

Berdasarkan Tabel 4. Perlakuan perbedaan suhu pengeringan terhadap serat kasar tepung belimbing manis didapatkan hasil tertinggi pada perlakuan perlakuan S2 sebesar 16,38\% dan terendah pada perlakuan S1 yaitu sebesar 13,36\%. Hal ini dapat terjadi karena adanya perbedaan penggunaan suhu, penggunaan suhu tinggi dalam pengeringan dapat meningkatkan kandungan serat pada tepung belimbing manis begitu juga sebaliknya. Hal ini juga sejalan dengan penelitian Simanjuntak dkk. (2014) yang menyatakan bahwa penggunaan suhu yang tinggi atau menurunnya kadar air dalam bahan pangan dapat mengakibatkan senyawa seperti lemak, protein, dan karbohidrat akan meningkat, yang mana apabila kandungan karbohidrat meningkat maka kadar serat dalam bahan akan meningkat.

\section{Gula Total}

Berdasarkan Tabel 4. hasil gula total pada tepung belimbing manis tertinggi pada perlakuan A2 sebesar 31,37\% dan terendah pada perlakuan A3 sebesar $12,87 \%$. Hal ini dapat disebabkan karena perlakuan pendinginan yang dapat menghambat kerusakan enzimatis dan mikrobiologis, selain itu juga perbedaan penggunaan alat pengering. Hal ini sesuai dengan Brantas (2017) yang menyatakan bahwa dengan penyimpanan suhu rendah dapat menghambat 
kerusakan makanan, antara lain yaitu kerusakan fisiologis, kerusakan mikrobiologis, kerusakan enzimatis dan juga dapat menghasilkan reaksi hidrolisis yang berjalan secara sempurna sehingga terjadi peningkatan panas dan mempercepat reaksi hidrolisis yang dapat memecah molekul gula menjadi gula sederhana. Selain itu juga, menurut Rif'an dkk. (2017) bahwa kecepatan aliran udara serta suhu yang tinggi dalam ruang oven dryer dapat menyebabkan air menguap lebih cepat sehingga terjadi perpindahan panas secara konveksi dan radiasi yang dapat menimbulkan air menguap lebih cepat, selain itu elemen panas yang berdekatan dengan bahan dan yang terdapat pada dinding oven dapat membantu mentransfer energi lebih merata dengan dibantu oleh kipas oven untuk sirkulasi udara. Sedangkan pada pengering cabinet dryer hanya menggunakan satu pemanas yang mana hal tersebut dapat mengakibatkan proses penguapan panas kurang optimal.

Berdasarkan Tabel 4. Perlakuan perbedaan suhu pengeringan terhadap gula total tepung belimbing manis didapatkan hasil tertinggi pada perlakuan perlakuan S2 sebesar 29,12\% dan terendah pada perlakuan S1 yaitu sebesar 12,08\%. Hal ini dapat terjadi karena adanya peningkatan suhu yang dapat mempengaruhi jumlah gula total dalam tepung belimbing manis. Hal ini sesuai dengan Sutrisno (2014) bahwa pemanasan dengan suhu yang tinggi akan mempengaruhi kadar gula dalam bahan pangan, hal ini dikarenakan kadar air mengalami penurunan sehingga nilai kadar gula meningkat. Hal ini sejalan dengan Shabrina \& Susanto (2017) bahwa apabila menggunakan suhu yang tinggi dalam proses pengeringan makan akan semakin banyak molekul air yang teruapkan sehingga menyebabkan kandungan air menurun dan gula total meningkat. Pada proses pengeringan akan mengakibatkan hilangnya air yang terdapat pada bahan akibat dari penguapan, sehingga terjadi peningkatan pada kadar gula total.

\section{Intensitas warna}

Berdasarkan Tabel 5. hasil tingkat kecerahan (L) tertinggi pada perlakuan A2S1 sebesar 63,56 dan terendah pada perlakuan A3S2 sebesar 49,36. Hal ini dapat menunjukkan bahwa semakin besar nilai L maka tepung belimbing manis akan semakin cerah. Menurut Ariani dkk. (2019) yang menyatakan bahwa semakin besar nilai L maka akan semakin cerah warnanya., yang mana nilai L menunjukkan kesan cerah atau gelap dimana tingkat kecerahan memiliki nilai antara 0 untuk warna gelap dan 100 untuk warna cerah. Berdasarkan nilai yang terdapat dalam Tabel 5 tanpa adanya proses freezing dapat mengakibatkan nilai L semakin rendah, karena akan mengakibatkan warna yang cenderung gelap sehingga sejalan dengan Nuraeni (2018) Menyatakan bahwa tepung terubuk yang 
diberi perlakuan blanching dapat menurunkan warna coklat pada bahan, dikarenakan blanching dapat mengiinaktifkan enzim yang dapat menimbulkan warna coklat pada bahan.

Tabel 5. Hasil Analisis Tingkat Kecerahan (L), Kemerahan (a+), dan Kekuningan (b+) Tepung Belimbing Manis dengan Perbedaan Metode dan Suhu Pengeringan

\begin{tabular}{|c|c|c|c|c|}
\hline \multirow{2}{*}{\multicolumn{2}{|c|}{ Perlakuan }} & \multicolumn{3}{|c|}{ Intensitas Warna } \\
\hline & & $\mathrm{L}$ & $a+$ & $\mathrm{b}$ \\
\hline A1S1 & $($ Freezing + cabinet dryer $)+\left(\right.$ suhu $\left.55^{\circ} \mathrm{C}\right)$ & $59,70 \mathrm{~b}$ & $9,33 \mathrm{~d}$ & $15,36 \mathrm{~d}$ \\
\hline $\mathrm{A} 2 \mathrm{~S} 1$ & (Freezing+oven)+(suhu $\left.55^{\circ} \mathrm{C}\right)$ & $63,56 \mathrm{a}$ & $8,70 \mathrm{e}$ & $12,36 \mathrm{e}$ \\
\hline A3S1 & (Cabinet dryer) $+\left(\right.$ suhu $\left.55^{\circ} \mathrm{C}\right)$ & $53,00 \mathrm{~d}$ & $10,50 \mathrm{c}$ & $19,63 \mathrm{~b}$ \\
\hline $\mathrm{A} 4 \mathrm{~S} 1$ & (Oven)+(suhu $\left.55^{\circ} \mathrm{C}\right)$ & $56,26 \mathrm{c}$ & $10,43 \mathrm{c}$ & $19,06 \mathrm{~b}$ \\
\hline A1S2 & (Freezing cabinet dryer) $+\left(\right.$ suhu $\left.60^{\circ} \mathrm{C}\right)$ & $58,76 \mathrm{~b}$ & $10,36 \mathrm{c}$ & $18,76 \mathrm{bc}$ \\
\hline $\mathrm{A} 2 \mathrm{~S} 2$ & (Freezing+oven)+(suhu $\left.60^{\circ} \mathrm{C}\right)$ & $59,70 \mathrm{~b}$ & $10,16 \mathrm{c}$ & $17,43 \mathrm{c}$ \\
\hline A3S2 & $($ Cabinet dryer $)+\left(\right.$ suhu $\left.60^{\circ} \mathrm{C}\right)$ & $49,36 \mathrm{e}$ & $12,56 \mathrm{a}$ & $22,50 \mathrm{a}$ \\
\hline A4S2 & $($ Oven $)+\left(\right.$ suhu $\left.60^{\circ} \mathrm{C}\right)$ & $51,06 \mathrm{e}$ & $11,66 \mathrm{~b}$ & $19,86 \mathrm{~b}$ \\
\hline
\end{tabular}

Keterangan : Angka yang diikuti huruf yang sama meunjukkan tidak berbeda nyata berdasarkan uji DMRT $(\alpha=5 \%)$

Berdasarkan Tabel 5. hasil nilai kemerahan (a+) tertinggi pada perlakuan A3S2 sebesar 12,56 dan terendah pada perlakuan A2S1 sebesar 8,70. Hal ini terjadi diduga karena saat proses pengeringan menggunakan suhu yang tinggi, adanya perbedaan alat pengeringnya serta proses freezing pada pembuatan tepung belimbing manis yang mana akan mengakibatkan warna dari tepung belimbing manis akan menjadi coklat/gelap. Dengan adanya pre-treatment berupa penggunaan microwave dan pendinginan dapat mengurangi warna kegelapan/kemerahan pada tepung belimbing manis. Hal ini sejalan dengan Nuraeni (2018) bahwa dengan adanya blanching dapat menginaktifkan enzim yang dapat menyebabkan warna coklat pada bahan, sehingga dapat memperbaiki warna pada tepung terubuk.

Berdasarkan Tabel 5. hasil nilai kekuningan (b+) tertinggi pada perlakuan A3S2 sebesar 22,50 dan terendah pada perlakuan A2S1 sebesar 12,36. Hal ini dapat terjadi karena adanya penggunaan suhu tinggi pada saat proses pengeringan berlangsung serta diduga karena adanya proses pre-treatment berupa freezing dan penggunaan microwave. Hal ini didukung oleh Shabrina \& Susanto (2017) yang menyatakan bahwa semakin tinggi penggunaan suhu dan lama proses pengeringan akan mampu menurunkan warna kekuningan. Penurunan ini diakibatkan oleh terjadinya browning pada bahan pangan, yang mana proses pembentukan pigmen warna kuning akan berubah menjadi coklat serta reaksi browning ini terdiri atas reaksi maillard yang dimana wana akan berubah dikarenakan dengan adanya proses pengolahan akibat panas. 


\section{KESIMPULAN}

Terdapat interaksi antara perlakuan perbedaan metode pengeringan dan suhu pengeringan terhadap intensitas warna tepung belimbing manis. Terdapat pengaruh nyata pada perlakuan perbedaan suhu pengeringan terhadap aktivitas antioksidan, gula total, serat kasar, kadar air, dan rendemen tepung belimbing manis. Terdapat pengaruh nyata pada perlakuan perbedaan metode pengeringan terhadap aktivitas antioksidan, gula total, serat kasar, dan rendemen tepung belimbing manis. Perlakuan terbaik dihasilkan oleh sampel A2S1 (Freezing+oven dan suhu $55^{\circ} \mathrm{C}$ ) yang memiliki nilai kadar air 17,64\%, Vitamin C 41,00 mg/100g, serat kasar 16,24\%, gula total 19,25\%, rendemen $12,451 \%$, aktivitas antioksidan $17,28 \%$, intensitas warna kecerahan (+) 63,56, intensitas warna kemerahan (+) 8,70 , intensitas warna kekuningan (+) 12,36.

\section{DAFTAR PUSTAKA}

Ariani, Y., Bintoro, N., \& Karyadi, J. N. W. 2019. Kinetika Perubahan Kualitas Fisik Buah Mangga Selama Pengeringan Beku dengan Perlakuan Pendinginan Awal dan Ketebalan Irisan. Agritech, 39(4), pp.298. DOI:https://doi.org/10.22146/agritech.42599

AOAC. 2002. Guidelines for Validation of Microbiological Methods for Food and Enviromental Surfaces. AOAC Internasional.

AOAC. 2005. Official Methods of Analysis of The Association of Official Analytical Chemist. AOAC Inc., Washington

Asgar, A. 2017. Pengaruh Suhu Penyimpanan dan Jumlah Perforasi Kemasan Terhadap Karakteristik Fisik dan Kimia Brokoli (Brassica oleracea var. Royal G) Fresh-Cut. Jurnal Hortikultura, 27(1), pp.127. DOI:http://dx.doi.org/10.21082/jhort.v27n1.2017.p127-136

Baswarsiati. 2017. Karakteristik, Penciri dan Keunggulan Belimbing Varietas Karangsari sebagai Varietas Unggul Asal Jawa Timur. Jurnal Ilmu- Ilmu Pertanian “AGRIKA," 11(November), pp.191-205.

Brantas, B. 2017. Karakteristik Fisiko Kimia Tepung Buah Apel (Malus domestica) Dengan Perlakuan Perbedaan Metode Pengeringan dan Kultivar Apel. Skripsi. Universitas Muhammadiyah Malang.

Departemen Pertanian, 2009. Pedoman Umum Pengembangan Usaha Agribisnis Pedesaan (PUAP). Jakarta. Departemen Pertanian. 27.

Ditjen PPHP. 2012. Kebijakan Pengembangan Tepung Lokal (Cassava). Direktorat Jenderal Pengolahan dan Pemasaran Hasil Pertanian. Jakarta.

Erlina, T. 2012. Uji Model Alat Pengering Tipe Rak Dengan Kolektor Surya (Studi Kasus Untuk Pengeringan Cabai Merah (Capsium annum Var. Longum). Jurnal Neutrino. DOI: https://doi.org/10.18860/neu.v0i0.1608

Kusuma, I. G. N. S., Putra, I. N. K., \& Darmayanti, L. P. T. 2019. Pengaruh Suhu Pengeringan Terhadap Aktivitas Antioksidan Teh Herbal Kulit Kakao (Theobroma cacao L.). Jurnal Ilmu dan Teknologi Pangan (ITEPA), 8(1), pp.85. DOI: https://doi.org/10.24843/itepa.2019.v08.i01.p10 
Kuliahsari, D. E., Fauzi, M., Diniyah, N., \& Rusdianto, A. S. 2018. Penggunaan Vitamin C dan Suhu Pengeringan Pada Pembuatan Chip (Irisan Kering) Labu Kuning La3 (Cucurbita moschata). Jurnal Penelitian Pascapanen Pertanian, 14(2), pp.108. DOI: ttps://doi.org/10.21082/jpasca.v14n2.2017.108115

Lim, Y. Y., Lim, T. T., \& Tee, J. J. 2007. Antioxidant properties of several tropical fruits: A comparative study. Food Chemistry, 103(3), pp.1003-1008. DOI:https://doi.org/10.1016/j.foodchem.2006.08.038

Murti, K. H. 2017. Pengaruh Suhu Pengeringan Terhadap Kandungan Vitamin C Buah Cabai Keriting Lado F1 (Capsicum annuum L). Jurnal Keteknikan Pertanian Tropis dan Biosistem, 5(3), pp.245-256. https://jkptb.ub.ac.id/index.php/jkptb/article/view/434

Nilasari, O. W., Susanto, W. H., \& Maligan, J. M. 2017. Pengaruh Suhu dan Lama Pemasakan Terhadap Karakteristik Lempok Labu Kuning (Waluh). Jurnal Pangan dan Agorindustri, 5(3), pp.15-26. https://jpa.ub.ac.id/index.php/jpa/article/view/537

Nuraeni, L. 2018. Pengaruh Suhu dan Lama Pengeringan Terhadap Karakteristik Tepung Terubuk (Saccharum edule Hasskarl). Angewandte Chemie International Edition, 6(11), pp.951-952., 2(1).

Paramita, O. 2013. Kajian Proses Pembuatan Tepung Buah Mangga (Mangivera indica L) Varietas Arumanis dengan Suhu Perendaman yang Berbeda. Jurnal Bahan Alam Terbarukan, 1(1), pp.1-1. DOI:https://doi.org/10.15294/jbat.v1i1.2542

Patras, A., Brunton, N. P., O'Donnell, C., \& Tiwari, B. K. 2010. Effect of thermal processing on anthocyanin stability in foods; mechanisms and kinetics of degradation. Trends in Food Science and Technology, 21(1), pp.3-11. DOI:https://doi.org/10.1016/j.tifs.2009.07.004

Rahayuningtyas, A., \& Kuala, S. I. 2016. Pengaruh Suhu dan Kelembaban Udara Pada Proses Pengeringan Singkong (Studi Kasus: Pengering Tipe Rak). ETHOS (Jurnal Penelitian Dan Pengabdian), pp.99. DOI:https://doi.org/10.29313/ethos.v0i0.1663

Ratnasari, Y. N. 2014. Pengaruh Suhu dan Lama Perendaman Terhadap Laju Pengeringan Kacang Hijau pada Kinerja Alat Rotary Dryer. Skripsi. Universitas Diponegoro.

Rif'an, Nurrahman, \& Aminah, S. 2017. Pengaruh Jenis Alat Pengering Terhadap Karakteristik Fisik, Kimia dan Organoleptik Sup Labu Kuning Instan. Jurnal Pangan dan Gizi, 7(2), pp.104-116. DOI: https://doi.org/10.26714/jpg.7.2.2017.104-116

Shabrina, Z. U., \& Susanto, W. H. 2017. Pengaruh Suhu dan Lama Pengeringan Dengan Metode Cabinet Dryer Terhadap Karakteristik Manisan Kering Apel Varietas Anna (Malus domestica Borkh) T. Jurnal Pangan dan Agroindustri, 5(3), pp.60-71. https://jpa.ub.ac.id/index.php/jpa/article/view/545

Silva, K. D. R. R., \& Sirasa, M. S. F. 2018. Antioxidant properties of selected fruit cultivars grown in Sri Lanka. Food Chemistry, 238, pp.203-208. DOI:https://doi.org/10.1016/j.foodchem.2016.08.102 
Simanjuntak, L., Harun, N., \& Efendi, R. 2014. Penerimaan Panelis Terhadap Teh Herbal dari Kulit Buah Manggis (Garcinia mangostana L.) dengan Perlakuan Suhu Pengeringan. Sagu, 13(2), pp.7-18. DOI:http://dx.doi.org/10.31258/sagu.v13i2.2575

Subandi, Suparman, \& Sukiyadi. 2015. Modifikasi Oven Bekas sebagai Alat Pengering Multi Fungsi Modification Second-hand Oven as a Tool Multi Function Dryer. Jurnal Ilmiah Teknik Pertanian, 7(2), pp.113-123. DOI:https://doi.org/10.25181/tektan.v7i2.884

Sudarmadji S, Haryono B, dan Grahadi. 1997. Prosedur Analisa untuk Bahan Makanan dan Pertanian. Liberty: Yogyakarta. ISBN 979.499.227.5

Wulansari, I. D., Admadi, B., \& Mulyani, S. 2020. Pengaruh Suhu Penyimpanan terhadap Kerusakan Antioksidan Ekstrak Daun Asam (Tamarindus indica L). Jurnal Rekayasa dan Manajemen Agroindustri, 8(4), pp.544. DOI:https://doi.org/10.24843/jrma.2020.v08.i04.p07

Yue, X., and Xu, Z. 2008. Changes of Anthocyanins, Anthocyanidins, Antioxidant Activity in Bilberry Extract during Dry Heating. Journal of Food Science, 73(6), pp. 494-499.DOI: https://doi.org/10.1111/j.1750-3841.2008.00845.x

Yuwono, S. dan T. Susanto. 2001. Pengujian Fisik Pangan. Fakultas Teknologi Pangan. Skripsi. Universitas Brawijaya. Malang 